\title{
MODIFIKASI TEPUNG UMBI TALAS BOGOR (COLOCASIA ESCULENTUM (L) SCHOTT) DENGAN TEKNIK OKSIDASI SEBAGAI BAHAN PANGAN PENGGANTI TEPUNG TERIGU
}

\author{
Dessy Ariyanti ${ }^{*}$, Catarina Sri Budiyati dan Andri Cahyo Kumoro \\ Jurusan Teknik Kimia, Fakultas Teknik, Universitas Diponegoro \\ Jl. Prof. Soedarto, SH, Tembalang, Semarang, 50275, Telp/fax: (024)7460058/(024)76480675 \\ ${ }^{*}$ Penulis korespondensi: dessy@undip.ac.id
}

\begin{abstract}
MODIFIED BOGOR TARO TUBER FLOUR (COLOCASIA ESCULENTUM (L) SCHOTT) USING OXIDATION TECHNIQUE AS A WHEAT FLOUR REPLACEMENT. Bogor taro (Colocasia esculentum (L) Schott) is one of the local resources which can be used as raw material for flour and starch production. They are easy to cultivate in tropical and sub-tropical area such as Indonesia. Tubers of Bogor taro contain a lot of carbohydrates and the flour can be modified using several technique of modification in order to achieve the similar content and properties as wheat flour. The objective of this research was to upgrade the quality of tuber Bogor taro flour by studying the effect of suspension consistency (40;30;20;10\%), concentration of catalyst $(0 ; 0.1 \% ; 0.2 \%)$ and $\mathrm{H}_{2} \mathrm{O}_{2}(1 \% ; 2 \%$ and $3 \%)$ as oxidizer and temperature of oxidation process $\left(30 ; 40 ; 50^{\circ} \mathrm{C}\right)$. The results showed that the use of $40 \%$ suspension consistency, $0.1 \%$ catalyst concentration, $2 \% \mathrm{H}_{2} \mathrm{O}_{2}$ concentration and $30^{\circ} \mathrm{C}$ of oxidation temperature at 30 minutes gave the most optimum results in terms of swelling power with $7 \mathrm{~g} / \mathrm{g}$ and water solubility $4 \%$ with taking the technical and economic aspects of the process as consideration. Swelling power and water solubility of modified tuber of Bogor taro flour were higher compared to the native ones, which successively $4.3 \mathrm{~g} / \mathrm{g}$ and $2 \%$. However, in organoleptic analyses showed that the cookies made from modified flour of Bogor taro tuber still have weaknesses such as a bitter taste and fragile textures compared to the cookies made from wheat flour.
\end{abstract}

Keywords: flour oxidation; hydrogen peroxide; swelling power; water solubility

\begin{abstract}
Abstrak
Tanaman talas Bogor (Colocasia esculentum (L) Schott) sangat mudah dibudidayakan di daerah tropik dan sub-tropik, termasuk Indonesia. Umbi talas Bogor kaya akan karbohidrat, sehingga dapat digunakan sebagai sumber energi yang potensial bagi manusia melalui berbagai proses modifikasi. Tujuan dari penelitian ini adalah memperbaiki kualitas tepung umbi talas Bogor dengan mengkaji pengaruh konsentrasi suspensi, katalis, oksidator, dan temperatur dari proses modifikasi dengan cara oksidasi menggunakan larutan hidrogen peroksida $\left(\mathrm{H}_{2} \mathrm{O}_{2}\right)$. Variabel yang dikaji adalah suspensi tepung dengan air (40, 30, 20, dan 10\%), waktu reaksi (30, 60, 90, dan 120 menit, konsentrasi katalis (0;0,1\%;0,2\%), konsentrasi oksidator $(1 \%, 2 \%$ dan $3 \%)$ dan temperatur $\left(30 ; 40 ; 50^{\circ} \mathrm{C}\right)$. Hasil penelitian menunjukkan bahwa penggunaan konsentrasi suspensi 40\%, konsentrasi katalis 0,1\%, konsentrasi $\mathrm{H}_{2} \mathrm{O}_{2} 2 \%$ dan temperatur $30^{\circ} \mathrm{C}$ pada waktu oksidasi 30 menit memberikan hasil yang paling optimum ditinjau dari daya kembang (swelling power) dengan nilai $7 \mathrm{~g} / \mathrm{g}$ dan kelarutannya dalam air yaitu 4\% dengan mempertimbangkan aspek teknis dan ekonomis dari proses. Hasil penelitian ini menunjukkan bahwa penggunaan $\mathrm{H}_{2} \mathrm{O}_{2}$ sebagai oksidator cukup efektif dalam meningkatkan nilai daya kembang tepung talas Bogor yang sebelumnya hanya 4,3 g/g menjadi $7 \mathrm{~g} / \mathrm{g}$, dimana nilai tersebut telah masuk dalam rasio daya kembang tepung terigu yaitu 6,8-7,9 g/g. Namun oksidator $\mathrm{H}_{2} \mathrm{O}_{2}$ tidak cukup efektif dalam meningkatkan nilai kelarutan tepung dalam air yang sebelumnya hanya $2 \%$ menjadi $4 \%$, dimana nilai tersebut masih dibawah rasio kelarutan tepung terigu yaitu 6,3-7,3\%. Selain itu uji organoleptik pada kue kering berbahan baku tepung umbi talas Bogor teroksidasi menunjukkan kelemahan berupa rasa yang agak pahit dan tekstur yang terlalu rapuh dibandingkan dengan kue kering yang menggunakan bahan baku tepung terigu.
\end{abstract}

Kata kunci : oksidasi tepung; hidrogen peroksida; daya kembang; kelarutan 
How to Cite This Article: Ariyanti, D., Budiyati, C.S., dan Kumoro, A.C., (2014), Modifikasi Tepung Umbi Talas Bogor (Colocasia Esculentum (L) Schott) dengan Teknik Oksidasi Sebagai Bahan Pangan Pengganti Tepung Terigu, Reaktor, 15(1), 1-9, http://dx.doi.org/ 10.14710/reaktor.15.1.1-9

\section{PENDAHULUAN}

Tanaman talas Bogor (Colocasia esculentum (L) Schott) sangat mudah dibudidayakan di daerah tropik dan sub-tropik, termasuk Indonesia. Umbi talas Bogor kaya akan karbohidrat, sehingga merupakan sumber energi yang potensial bagi manusia. Karena butir patinya yang sangat kecil, yaitu antara 1-5 $\mu \mathrm{m}$ (Agama-Acevedo dkk., 2011) dan kandungan amylose yang tinggi (20-25\%), pati dalam umbi talas sangat mudah dicerna dengan bantuan $\alpha$-amylase dalam air liur menjadi gula sederhana. Hal ini menjadikan umbi talas sangat cocok menjadi bahan makanan terutama untuk balita yang menderita alergi makanan dan orang dewasa yang mengalami gangguan pencernaan (Onwueme, 1978). Umbi talas Bogor juga merupakan sumber protein, vitamin $\mathrm{C}$, tiamin, riboflavin, niasin dan mineral yang bagus (Niba, 2003). Oleh karena itu, usaha untuk meningkatkan diversifikasi produk berbasis talas baik untuk berbagai keperluan dalam negeri dan ekspor harus terus digalakkan. Hal tersebut akan meningkatkan kebutuhan akan tersedianya tepung umbi talas Bogor termodifikasi sebagai pengganti tepung terigu.

Kajian mengenai daya kembang dan kelarutan pada pati talas dan pati talas termodifikasi telah dilakukan oleh beberapa peneliti. Tepung talas yang diperoleh dari penelitian terdahulu belum memenuhi sifat-sifat fungsional tepung yang setara dengan tepung terigu Amerika maupun Korea, terutama untuk perubahan ukuran, struktur permukaan, nilai daya kembang, kelarutan dalam air, kapasitas serap air dan minyak sehingga tidak dapat digunakan sepenuhnya untuk mengganti tepung terigu dalam pembuatan roti dan biskuit. Pati teroksidasi, pati terasetilasi dan pati yang dimodifikasi dengan pelembaban dan pemanasan lebih mudah larut jika dibandingkan dengan pati asli. Sedangkan pati dengan ikatan silang lebih sukar larut. Akan tetapi, semua pati talas termodifikasi yang diperoleh mempunyai daya kembang yang lebih rendah jika dibandingkan dengan pati talas asli. Selain itu, daya kembang dan kelarutan pada pati talas termodifikasi ternyata dipengaruhi oleh $\mathrm{pH}$, dan nilainya cukup besar pada pH 2,0 dan 10,0 (Alam dan Hasnain, 2009). Chung dkk. (2008) melaporkan bahwa butir pati jagung teroksidasi dapat dicerna jauh lebih cepat dibandingkan dengan pati asli, pati terasetilasi, da terhidroksipropilasi. Proses oksidasi pati dapat dilakukan dengan mereaksikan luluhan pati dengan natrium hipokhlorit pada $\mathrm{pH} 9,5$ dan $35^{\circ} \mathrm{C}$ selama 30 menit (Chung dkk., 2008; Akintayo dan Akintayo, 2009). Oksidasi juga dapat dilakukan dengan mereaksikan suspensi pati dalam larutan natrium sulfat yang $\mathrm{pH}$ nya 11,0 dengan larutan $\mathrm{H}_{2} \mathrm{O}_{2}$ encer $(5 \%)$ secara bertetes-tetes selama 10 jam pada pH 5,5 (Alam dan Hasnain, 2009). Namun, seiring dengan gencarnya pemerhati lingkungan dan Food and Drug Association (FDA) dalam mengendalikan penggunaan sodium hipokhlorit dalam pengolahan pangan, maka $\mathrm{H}_{2} \mathrm{O}_{2}$ mulai menggantikan sodium hipokhlorit karena lebih ramah lingkungan dan tidak meninggalkan residu yang berbahaya dalam produk pangan. Oksidasi dengan $\mathrm{H}_{2} \mathrm{O}_{2}$ dapat dilakukan tanpa katalis atau dengan katalis besi/tembaga sulfat (Wing dan Willet, 1997) Pati teroksidasi banyak digunakan dalam industri makanan karena mempunyai viskositas pasta yang rendah, stabilitas termal yang tinggi, warna yang cerah, dan kemampuan melekat/mengikat dan membentuk lapisan yang baik, selain itu pati teroksidasi juga mempunyai daya kembang yang besar (Martinez-Bustos dkk., 2007).

Dalam rangka memperbaiki kualitas tepung umbi talas Bogor dalam hal ini nilai daya kembang dan kelarutan dalam air, maka penelitian ini mengkaji pengaruh konsentrasi suspensi, konsentrasi katalis, konsentrasi oksidator, dan temperatur dari proses modifikasi dengan cara oksidasi menggunakan larutan $\mathrm{H}_{2} \mathrm{O}_{2}$ (Paravuori dkk., 1995; Alam dan Hasnain, 2009). Larutan $\mathrm{H}_{2} \mathrm{O}_{2}$ dipilih sebagai pengoksidasi karena larutan ini mudah didapat di pasaran, mudah pengendaliannya sehingga tidak mencemari lingkungan dan dapat bereaksi dengan cepat pada suhu kamar $\left(30^{\circ} \mathrm{C}\right)$ atau pada suhu $40^{\circ} \mathrm{C}$.

\section{METODE PENELITIAN Bahan}

Bahan baku yang digunakan dalam penelitian ini adalah tepung umbi talas Bogor (Colocasia esculenta (L) Schott) dengan karakteristik seperti pada Tabel 1. Akuades diperoleh dari Unit Reverse Osmosis (RO) yang tersedia di Jurusan Teknik Kimia, Fakultas Teknik, Universitas Diponegoro. Sementara itu, semua reagan kimia dengan kualitas analisis dibeli dari distributor resmi Sigma-Aldrich Co. Inc. di Semarang.

Tabel 1. Karakteristik tepung umbi talas Bogor

\begin{tabular}{lcc}
\hline Parameter & $\begin{array}{c}\text { Tepung umbi } \\
\text { talas Bogor }\end{array}$ & $\begin{array}{c}\text { SNI Tepung } \\
\text { Terigu }\end{array}$ \\
\hline Air (\%) & 9,844 & Maks. 14,5 \\
Karbohidrat (\%) & 80,572 & - \\
Protein (\%) & 3,491 & Min. 7 \\
Lemak (\%) & 2,989 & - \\
Abu (\%) & 3,103 & Maks. 7 \\
\hline
\end{tabular}

\section{Prosedur Penelitian}

Tepung umbi talas Bogor dioksidasi dengan larutan $\mathrm{H}_{2} \mathrm{O}_{2}$ dalam lingkungan asam menggunakan katalis ion logam tembaga. Dua puluh lima gram tepung didispersikan di dalam akuades untuk memperoleh suspensi dengan konsentrasi tepung sesuai variabel yang telah ditentukan. Sebelum reaksi oksidasi dilakukan, $\mathrm{CuSO}_{4} .5 \mathrm{H}_{2} \mathrm{O}$ yang mengandung 
ion logam tembaga dilarutkan dalam akuades untuk memperoleh konsentrasi ion $\mathrm{Cu}^{2+}$ (sesuai variabel) atas dasar berat tepung kering. Selanjutnya, oksidasi dilakukan dengan pada suhu $30^{\circ} \mathrm{C}$ dengan pengadukan secara terus menerus (Parovuori dkk., 1995). Larutan $\mathrm{H}_{2} \mathrm{O}_{2} \quad 35 \%$ ditambahkan tetes demi tetes hingga mencapai konsentrasi yang diinginkan. Tepung teroksidasi yang diperoleh selanjutnya dicuci dengan akuades sebanyak 4 kali dengan volume masingmasing $900 \mathrm{ml}$, disaring dengan menggunakan kertas saring (ukuran pori $0,45 \mu \mathrm{m}$ ), dikeringkan dalam oven pada suhu $50^{\circ} \mathrm{C}$ selama 48 jam dan digiling hingga halus 100 mesh. Setiap sampel yang diperoleh kemudian dibungkus dengan plastik kedap udara dan disimpan pada suhu $28 \pm 2{ }^{\circ} \mathrm{C}$ untuk keperluan percobaan selanjutnya dan dianalisis daya kembang dan kelarutannya dalam air. Variabel yang dikaji adalah konsentrasi suspensi tepung talas dengan air $(50,40,30,20$, dan 10\%), waktu reaksi $(30,60,90$, dan 120 menit), katalis $(0,0,1$ dan $0,2 \%)$, oksidator (1, 2 dan 3\% berat tepung), dan temperatur (30, 40 dan $\left.50^{\circ} \mathrm{C}\right)$.

\section{Analisis Sifat Fungsional Tepung Umbi Talas Bogor Teroksidasi}

Analisis kelarutan dalam air dilakukan dengan menimbang 0,5 gr tepung kemudian dimasukkan ke dalam tabung reaksi ditambah $10 \mathrm{ml}$ akuades. Sampel kemudian dipanaskan dalam beaker glass berisi air pada suhu $60 \mathrm{C}$ selama 30 menit. Pada akhir pemanasan, sampel disentrifugasi (C-5 Test Tube Centrifuge) pada $1600 \mathrm{rpm}$ selama 15 menit dan $5 \mathrm{ml}$ supernatan ditampung dan dikeringkan sampai berat konstan dan kelarutan dalam air dinyatakan sebagai persen berat tepung terlarut dari larutan dipanaskan (Kainuma dkk., 1967). Analisis daya kembang dilakukan dengan menimbang sampel 0,1 gr kemudian dimasukkan ke dalam tabung reaksi ditambah $10 \mathrm{ml}$ akuades dan dipanaskan pada suhu $60^{\circ} \mathrm{C}$ selama 30 menit dengan pengadukan secara terus menerus. Sampel kemudian disentrifugasi (C-5 Test Tube Centrifuge) pada $1600 \mathrm{rpm}$ selama 10 menit untuk dipisahkan pasta dengan supernatannya. Bagian pastanya diambil lalu timbang (Leach dkk., 1959). Uji organoleptik juga dilakukan oleh 10 panelis untuk menganalisa produk berbahan baku tepung umbi talas Bogor temodifikasi.

\section{HASIL DAN PEMBAHASAN}

\section{Pengaruh Konsentrasi Suspensi}

Modifikasi tepung umbi talas Bogor dilakukan dengan proses oksidasi menggunakan $\mathrm{H}_{2} \mathrm{O}_{2}$ dengan konsentrasi $2 \%$ dari suspensi dalam lingkungan asam menggunakan katalis ion logam tembaga dengan konsentrasi $0,1 \%$ dari suspensi. Variabel yang dikaji adalah konsentrasi suspensi yaitu perbandingan jumlah tepung dengan air $(10,20,30$, dan $40 \%)$ serta waktu berlangsungnya proses oksidasi (0-150 menit), sedangkan parameter yang diukur adalah daya kembang dan kelarutan tepung hasil oksidasi dalam air.

Tabel 2 menunjukkan adanya kecenderungan peningkatan nilai daya kembang tepung talas Bogor setelah proses oksidasi akibat dari peningkatan konsentrasi suspensi dan peningkatan waktu oksidasi. Nilai daya kembang diasosiasikan dengan kandungan molekul amilopektin yang dapat diakses oleh molekul air. Depolimerisasi molekul amilosa oleh radikal hidroksil $(\mathrm{HO} \bullet)$ dari $\mathrm{H}_{2} \mathrm{O}_{2}$ mengakibatkan menurunnya derajat kristalinitas dan molekul air yang terdapat pada sistem dapat dengan mudah diakses oleh molekul amilopektin sehingga menyebabkan meningkatnya nilai daya kembang dari tepung (Matsugama dkk., 2009). Konsentrasi suspensi menyatakan jumlah pati yang terkandung dalam larutan tepung, dan dengan rasio jumlah oksidator yang sama maka peningkatan nilai daya kembang akan terjadi seiring peningkatan konsentrasi suspensi. Fenomena yang sama juga ditemukan pada oksidasi pati jagung oleh Wang dan Wang (2003) dan oksidasi pati Peruvian Carrot oleh Matsuguma dkk. (2009). Bahkan Chan dkk. (2009) menyatakan bahwa kandungan amilosa pada pati dapat menurunkan nilai daya kembang sedangkan konsentrasi amilopektin yang tinggi dapat meningkatkan daya kembang.

Pada konsentrasi suspensi $40 \%$, nilai daya kembang mencapai nilai tertinggi yaitu $7 \mathrm{~g} / \mathrm{g}$ dicapai dengan waktu oksidasi 30 menit. Waktu oksidasi menjadi parameter penting untuk mengontrol proses untuk mendapatkan produk yang diinginkan. Semakin lama proses oksidasi dapat menyebabkan terjadinya oksidasi lanjut pada molekul amilosa dan amilopektin menjadi gugus karboksil dan hidroksil yang memiliki kemungkinan untuk membentuk ikatan silang sehingga menurunkan nilai daya kembang (Lee dkk., 2005).

Tabel 2 juga menunjukkan pengaruh konsentrasi suspensi terhadap kelarutan tepung dalam air pada berbagai periode waktu proses oksidasi. Oksidasi tepung umbi talas Bogor dengan konsentrasi suspensi 10, 20 dan 30\% tidak dapat meningkatkan kelarutan tepung. Hanya dengan konsentrasi suspensi $40 \%$ nilai kelarutan tepung dalam air dapat meningkat dari $2 \%$ menjadi $4 \%$ pada 30 menit pertama kemudian konstan. Peningkatan kelarutan pada awal proses diakibatkan oleh depolimerisasi dan penurunan kekuatan struktur butir pati yang memicu terlepasnya amilosa. Hal ini sesuai dengan pernyataan Matsugama (2009), bahwa kelarutan tepung dalam air dipengaruhi oleh fraksi amilosa yang terlepas dari rantai pati.

\section{Pengaruh Konsentrasi Katalis}

Pengaruh katalis terhadap daya kembang dan kelarutan dalam air dalam modifikasi tepung umbi talas Bogor dengan proses oksidasi menggunakan $\mathrm{H}_{2} \mathrm{O}_{2}$ dapat dilihat pada Tabel 3. Variabel yang digunakan adalah perlakuan tanpa katalis, penambahan katalis $0,1 \%$ dan $0,2 \%$ pada tepung talas Bogor dengan konsentrasi suspensi $40 \%$ dan 
konsentrasi oksidator $\mathrm{H}_{2} \mathrm{O}_{2} \quad 2 \%$ serta waktu berlangsungnya proses oksidasi (0-150 menit).

Tabel 3 menunjukkan bahwa daya kembang dan kelarutan dalam air tepung hasil oksidasi yang paling tinggi adalah pada penambahan katalis $0,1 \%$ dengan waktu operasi 30 menit. Katalis berfungsi untuk menurunkan energi aktivasi dari sebuah reaksi kimia, sehingga dapat mempercepat reaksi yang terjadi. Penambahan katalis $0,1 \%$ dapat meningkatkan nilai daya kembang dari 4,3 g/g menjadi $7 \mathrm{~g} / \mathrm{g}$ serta kelarutan dalam air tepung hasil oksidasi dari 2\% menjadi 4\%. Capaian ini lebih baik dibandingkan dengan nilai daya kembang dan kelarutan dalam air tepung hasil oksidasi pada penambahan katalis $0,2 \%$.

Tolvanen dkk. (2013) melaporkan bahwa laju reaksi dekomposisi pati oleh $\mathrm{H}_{2} \mathrm{O}_{2}$ akan meningkat seiring dengan meningkatnya jumlah katalis yang digunakan. Akan tetapi, jika jumlah katalis yang ditambahkan terlalu banyak justru jumlah oksidan (peroksida) yang perlu dikatalisir tidak mencukupi sehingga kelarutan pati teroksidasi lebih rendah bila dibandingkan dengan penambahan katalis $0,1 \%$ dan kelebihan katalis ini tidak meningkatkan kinerja katalitiknya.

Tabel 2. Pengaruh konsentrasi suspensi terhadap daya kembang dan kelarutan tepung umbi talas Bogor termodifikasi dalam air dengan konsentrasi oksidator $\mathrm{H}_{2} \mathrm{O}_{2} 2 \%$, katalis $0,1 \%$ dari suspensi pada temperatur $30^{\circ} \mathrm{C}$ dengan berbagai waktu oksidasi

\begin{tabular}{ccccc}
\hline No. & Konsentrasi suspensi (\%) & $\begin{array}{c}\text { Waktu oksidasi } \\
(\text { menit })\end{array}$ & $\begin{array}{c}\text { Daya kembang } \\
(\mathrm{g} / \mathrm{g})\end{array}$ & $\begin{array}{c}\text { Kelarutan } \\
(\%)\end{array}$ \\
\hline 1 & $10 \%$ & 0 & 4,30 & 2,00 \\
2 & & 30 & 4,40 & 2,00 \\
3 & & 60 & 4,97 & 2,00 \\
4 & & 90 & 5,47 & 2,00 \\
5 & & 120 & 5,83 & 2,00 \\
6 & $20 \%$ & 0 & 4,30 & 2,00 \\
7 & & 30 & 5,00 & 2,00 \\
8 & & 60 & 4,70 & 2,00 \\
9 & & 90 & 4,40 & 2,00 \\
10 & $30 \%$ & 120 & 5,00 & 2,00 \\
11 & & 0 & 4,30 & 2,00 \\
12 & & 30 & 6,40 & 2,00 \\
13 & & 60 & 5,70 & 2,00 \\
14 & & 90 & 5,00 & 2,00 \\
15 & & 120 & 6,00 & 2,00 \\
16 & $40 \%$ & 0 & 4,30 & 2,00 \\
17 & & 30 & 7,00 & 4,00 \\
18 & & 60 & 6,57 & 4,00 \\
19 & & 90 & 6,47 & 4,00 \\
20 & & 120 & 5,63 & 4,00 \\
\hline
\end{tabular}

Tabel 3. Pengaruh penambahan katalis terhadap daya kembang dan kelarutan dalam air tepung umbi talas Bogor termodifikasi dengan konsentrasi oksidator $\mathrm{H}_{2} \mathrm{O}_{2} 2 \%$, konsentrasi suspensi $40 \%$ pada temperatur $30^{\circ} \mathrm{C}$ dengan berbagai waktu oksidasi

\begin{tabular}{ccccc}
\hline No. & $\begin{array}{c}\text { Penggunaan } \\
\text { Katalis (\%) }\end{array}$ & $\begin{array}{c}\text { Waktu oksidasi } \\
(\text { menit })\end{array}$ & $\begin{array}{c}\text { Daya kembang } \\
(\mathrm{g} / \mathrm{g})\end{array}$ & $\begin{array}{c}\text { Kelarutan } \\
(\%)\end{array}$ \\
\hline 1 & Tanpa katalis & 0 & 4,30 & 2,00 \\
2 & & 30 & 5,30 & 2,00 \\
3 & & 60 & 6,15 & 3,00 \\
4 & & 90 & 5,85 & 3,00 \\
5 & & 120 & 6,55 & 4,00 \\
6 & $0,1 \%$ & 0 & 4,30 & 2,00 \\
7 & & 30 & 7,00 & 4,00 \\
8 & & 60 & 6,57 & 4,00 \\
9 & & 90 & 6,47 & 4,00 \\
10 & & 120 & 5,63 & 4,00 \\
11 & $0,2 \%$ & 0 & 4,30 & 2,00 \\
12 & & 30 & 5,70 & 3,33 \\
13 & & 60 & 6,53 & 3,33 \\
14 & & 90 & 6,20 & 3,33 \\
15 & & 120 & 6,70 & 3,33 \\
\hline
\end{tabular}


Pada sistem yang menggunakan katalis $0,2 \%$ diperkirakan reaksi oksidasi terjadi lebih cepat dan memungkinkan terjadinya oksidasi lanjut yaitu konversi gugus karbonil menjadi gugus karboksil yang rentan terhadap pembentukan cross-linking diantara intra molekulnya. (Tolvanen dkk., 2013). Ikatan ini diduga menghambat proses absorpsi air oleh amilopektin sehingga nilai daya kembang cenderung menurun (Wang dan Wang, 2003).

Sementara itu, molekul amilosa yang terdepolimerisasi menjadi molekul rantai pendek mulai terlarut dalam air yang menyebabkan nilai kelarutan tepung dalam air juga meningkat secara signifikan. Hal ini sesuai dengan pernyataan Matsugama (2009), bahwa kelarutan tepung dalam air dipengaruhi oleh fraksi amilosa yang terlepas dari rantai pati.

\section{Pengaruh Konsentrasi Oksidator $\mathrm{H}_{2} \mathrm{O}_{2}$}

Modifikasi tepung umbi talas Bogor dengan proses oksidasi menggunakan $\mathrm{H}_{2} \mathrm{O}_{2}$ dengan konsentrasi suspensi $40 \%$ dalam lingkungan asam menggunakan katalis ion logam tembaga dengan konsentrasi $0,1 \%$ dari suspense dapat dilihat pada Tabel 4. Variabel yang dikaji adalah konsentrasi oksidator $\mathrm{H}_{2} \mathrm{O}_{2} \quad(1,2$, dan 3\%) serta waktu berlangsungnya proses oksidasi (0-150 menit), sedangkan parameter yang diukur adalah daya kembang dan kelarutan dalam air tepung hasil oksidasi.

Tabel 4 menunjukkan bahwa pada umumnya daya kembang tepung umbi talas Bogor meningkat dengan meningkatnya konsentrasi oksidator $\left(\mathrm{H}_{2} \mathrm{O}_{2}\right)$ dari $1 \mathrm{ke} \%$. Akan tetapi, meningkatkan konsentrasi oksidator dari 2 ke 3\% tidak meningkatkan daya kembang secara signifikan. Pada konsentrasi oksidator yang tinggi, maka jumlah katalis tidak mencukupi untuk bereaksi dengannya membentuk radikal hiroksil (HO•). Pada saat yang sama, $\mathrm{H}_{2} \mathrm{O}_{2}$ juga rentan mengalami dekomposisi. Hal ini menyebabkan efisiensi reaksi oksidasi justru menurun (Zhang dkk., 2012). Selain itu, proses oksidasi yang melebihi 30 menit, diduga terjadi oksidasi lanjut yaitu konversi gugus karbonil menjadi gugus karboksil yang rentan terhadap pembentukan cross-linking diantara intra molekulnya (karena konsentrasi oksidatornya juga tinggi). Ikatan ini diduga menghambat proses absorpsi air oleh amilopektin sehingga nilai daya kembang cenderung menurun (Wang and Wang, 2003). Tabel 4 juga menunjukkan pengaruh konsentrasi oksidator $\mathrm{H}_{2} \mathrm{O}_{2}$ terhadap kelarutan tepung dalam air pada berbagai periode waktu proses oksidasi. Kecenderungan yang sama terjadi pada proses oksidasi tepung umbi talas Bogor dengan konsentrasi oksidator $\mathrm{H}_{2} \mathrm{O}_{2}$ 1, 2 dan $3 \%$. Kelarutan tepung dalam air meningkat seiring peningkatan waktu proses oksidasi.

Pada konsentrasi oksidator $\mathrm{H}_{2} \mathrm{O}_{2} \quad 1 \%$ peningkatan nilai kelarutan berkisar dari 2 hingga $3,33 \%$, sedangkan pada konsentrasi oksidator $\mathrm{H}_{2} \mathrm{O}_{2}$ $2 \%$ peningkatan nilai kelarutan berkisar dari 2 hingga 4\% terjadi pada waktu 30 menit dan cenderung tetap pada peningkatan waktu proses. Pada konsentrasi oksidator $\mathrm{H}_{2} \mathrm{O}_{2} \quad 3 \%$ peningkatan nilai kelarutan berkisar dari 2 hingga 4\% dengan peningkatan yang bertahap di setiap variasi waktu proses.

Pada waktu proses yang sama yaitu 30 menit, nilai kelarutan tepung dalam air dari penggunaan konsentrasi oksidator $\mathrm{H}_{2} \mathrm{O}_{2} 2 \%$ terlihat lebih tinggi dibandingkan konsentrasi $1 \%$ maupun 3\%. Seperti yang telah dijelaskan sebelumnya, hal ini diduga akibat konsentrasi oksidator yang tinggi yang menyebabkan terjadinya oksidasi lanjut yaitu konversi gugus karbonil menjadi gugus karboksil yang rentan terhadap pembentukan cross-linking diantara intra molekulnya. Ikatan ini diduga menghambat keluarnya amilosa yang telah terpecah dari rantai pati (terperangkap), sehingga nilai kelarutan tepung dalam air menjadi lebih rendah (Chan dkk., 2009; Tethool dkk., 2012).

Tabel 4. Pengaruh konsentrasi oksidator $\mathrm{H}_{2} \mathrm{O}_{2}$ terhadap daya kembang (a) dan kelarutan dalam air (b) tepung umbi talas Bogor termodifikasi dengan konsentrasi suspensi $40 \%$, katalis $0,1 \%$ dari suspensi pada temperatur $30^{\circ} \mathrm{C}$ dan berbagai waktu oksidasi

\begin{tabular}{ccccc}
\hline No. & $\begin{array}{c}\text { Konsentrasi oksidator } \mathrm{H}_{2} \mathrm{O}_{2} \\
(\%)\end{array}$ & $\begin{array}{c}\text { Waktu oksidasi } \\
\text { (menit) }\end{array}$ & $\begin{array}{c}\text { Daya kembang } \\
(\mathrm{g} / \mathrm{g})\end{array}$ & $\begin{array}{c}\text { Kelarutan } \\
(\%)\end{array}$ \\
\hline 1 & $1 \%$ & 0 & 4,30 & 2,00 \\
2 & & 30 & 5,83 & 2,67 \\
3 & & 60 & 6,03 & 2,00 \\
4 & & 90 & 6,57 & 3,33 \\
5 & $2 \%$ & 120 & 6,23 & 3,33 \\
6 & & 0 & 4,30 & 2,00 \\
7 & & 30 & 7,00 & 4,00 \\
8 & & 60 & 6,57 & 4,00 \\
9 & & 90 & 6,47 & 4,00 \\
10 & $3 \%$ & 120 & 5,63 & 4,00 \\
11 & & 0 & 4,30 & 2,00 \\
12 & & 30 & 6,73 & 3,33 \\
13 & & 60 & 7,20 & 3,33 \\
14 & & 90 & 6,67 & 3,33 \\
15 & & 120 & 6,20 & 4,00 \\
\hline
\end{tabular}




\section{Pengaruh Temperatur Proses Oksidasi}

Pengaruh temperatur proses oksidasi terhadap daya kembang dan kelarutan tepung dalam air juga diamati dan hasilnya dapat dilihat pada Tabel 5 . Proses oksidasi pada suhu $30^{\circ} \mathrm{C}$ meningkatkan daya kembang pada waktu operasi 30 menit hingga $7 \mathrm{~g} / \mathrm{g}$ kemudian menurun pada penambahan waktu operasi. Kecenderungan yang berbeda terlihat pada suhu 40 dan $50^{\circ} \mathrm{C}$, daya kembang cenderung meningkat sedikit demi sedikit setiap penambahan waktu operasi. Peningkatan temperatur meningkatkan aktivitas oksidator $\mathrm{H}_{2} \mathrm{O}_{2}$ (Zhang dkk., 2012), sehingga struktur kristalin dari amilosa dapat dipecahkan dan amilopektin dapat mengabsorpsi air dari sistem sehingga meningkatkan kembang. Namun oksidasi lanjut juga diperkirakan terjadi sehingga amilopektin ikut terdepolimerisasi sehingga struktur yang seharusnya dapat mengabsorpsi air berkurang dan menyebabkan daya kembang menurun apabila temperatur dan waktu oksidasi ditingkatkan. Molekul amilosa dan amilopektin menjadi gugus karboksil dan hidroksil yang memiliki kemungkinan untuk membentuk ikatan silang sehingga menurunkan nilai daya kembang (Lee dkk., 2005).

Tabel 5 juga menunjukkan pengaruh temperatur proses terhadap data kelarutan tepung oksidasi dalam air. Kelarutan tertinggi terlihat pada proses oksidasi dengan temperatur operasi $50^{\circ} \mathrm{C}$. Hal ini terjadi karena peningkatan temperatur dapat membantu mempercepat proses oksidasi sehingga struktur kristalin dari amilosa dapat diturunkan dan banyak komponen amilosa yang terlepas ke sistem (Kumoro dkk., 2010). Selain itu, meningkatnya kelarutan tepung talas teroksidasi juga disebabkan oleh meningkatnya kemampuan hidrasi dari gugus fungsional yang dimasukkan (Zhang dkk., 2011).

\section{Mikrostruktur Tepung Umbi Talas Bogor Sebelum dan Setelah Proses Oksidasi}

Gambaran mikrostruktur granula pati pada tepung umbi talas Bogor sebelum dan setelah proses oksidasi dapat dilihat dari hasil pengamatan scanning electron microscopy (SEM) (Gambar 1a-1d). Gambar 1a dan $1 \mathrm{~b}$ menunjukkan perbandingan distribusi diameter butiran yang terdapat dalam tepung umbi talas Bogor dengan tepung umbi talas Bogor teroksidasi. Tepung umbi talas Bogor memiliki distribusi diameter bervariasi mulai $3,732 \mu \mathrm{m}$ hingga $17,22 \mu \mathrm{m}$, didominasi oleh granula yang berukuran sedang $(7-15 \mu \mathrm{m})$ sedangkan tepung umbi talas Bogor teroksidasi memiliki distribusi diameter bervariasi mulai $2,473 \mu \mathrm{m}$ hingga $16,34 \mu \mathrm{m}$, dimana granula yang berukuran kecil $(1-7 \mu \mathrm{m})$ sebanding dengan granula yang berukuran sedang $(7-15 \mu \mathrm{m})$.

Pada prinsipnya proses oksidasi yang terjadi merupakan reaksi degradasi pati yang dapat menurunkan derajat kristalinitas dari permukaan pati, sehingga dengan perlakuan yang sama dapat dihasilkan granula yang lebih kecil dibandingkan tepung umbi talas Bogor yang tidak teroksidasi. Perbedaan ukuran granula pati ini dapat mempengaruhi profil gelatinisasi pati. Pati yang memiliki ukuran yang besar akan memiliki suhu gelatinisasi yang relatif rendah dan viskositas maksimum yang cukup tinggi. Hal ini disebabkan granula pati lebih mudah menyerap air sehingga akan tergelatinisasi pada suhu lebih rendah dan mampu menyerap air yang banyak sebelum granulanya pecah yang kemudian dapat mencapai viskositas maksimum yang tinggi, ini terjadi pada granula pati tepung terigu dengan ukuran 10-35 $\mu \mathrm{m}$ (Kusnandar, 2011).

Gambar 1c dan 1d menunjukkan perbandingan bentuk dan kehalusan dari struktur butiran tepung talas asli dengan tepung talas teroksidasi.

Tabel 5. Pengaruh temperatur proses oksidasi terhadap daya kembang dan kelarutan dalam air tepung umbi talas Bogor termodifikasi dengan konsentrasi oksidator $\mathrm{H}_{2} \mathrm{O}_{2} 2 \%$, katalis $0,1 \%$ dari suspensi dan konsentrasi suspensi $40 \%$ dengan berbagai waktu oksidasi

\begin{tabular}{ccccc}
\hline No. & $\begin{array}{c}\text { Temperatur proses } \\
\text { oksidasi }\left({ }^{\circ} \mathrm{C}\right)\end{array}$ & $\begin{array}{c}\text { Waktu oksidasi } \\
(\text { menit })\end{array}$ & $\begin{array}{c}\text { Daya kembang } \\
(\mathrm{g} / \mathrm{g})\end{array}$ & $\begin{array}{c}\text { Kelarutan } \\
(\%)\end{array}$ \\
\hline 1 & 30 & 0 & 4,30 & 2,00 \\
2 & & 30 & 7,00 & 4,00 \\
3 & & 60 & 6,57 & 4,00 \\
4 & & 90 & 6,47 & 4,00 \\
5 & & 120 & 5,63 & 4,00 \\
6 & & 0 & 4,30 & 2,00 \\
7 & 40 & 30 & 5,13 & 4,00 \\
8 & & 60 & 6,50 & 4,00 \\
9 & & 90 & 6,50 & 4,00 \\
10 & & 120 & 6,57 & 4,00 \\
11 & & 0 & 4,30 & 2,00 \\
12 & 50 & 30 & 5,83 & 6,00 \\
13 & & 60 & 5,37 & 6,00 \\
14 & & 90 & 5,37 & 6,00 \\
15 & & 120 & 6,33 & 6,00 \\
\hline
\end{tabular}


Butiran tepung talas asli memiliki bentuk yang beragam dan tidak halus serta cenderung tidak terlepas sempurna dengan butiran lainnya, sementara tepung talas teroksidasi memiliki bentuk yang lebih halus dan terpisah sempurna dengan butiran lainnya. Karakteristik ini dimungkinkan dapat dihubungkan dengan tinggi rendahnya temperatur gelatinisasi dari tepung.

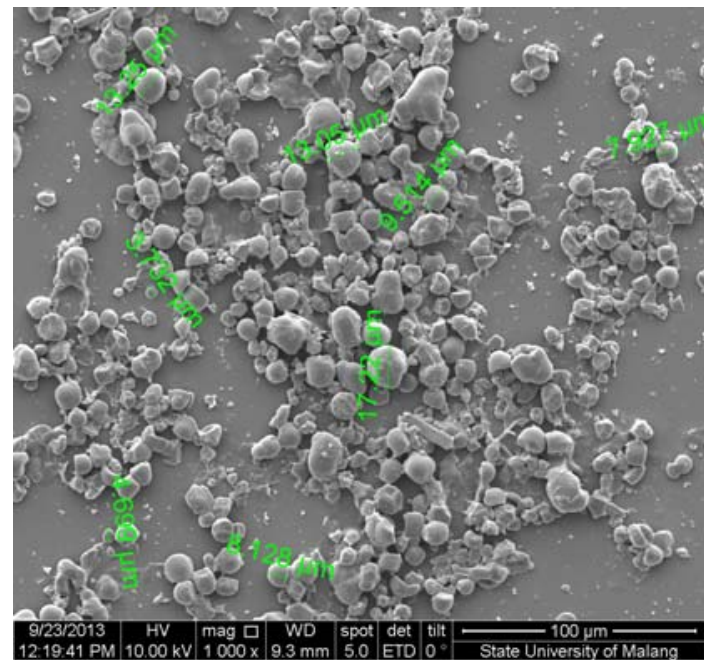

(a)

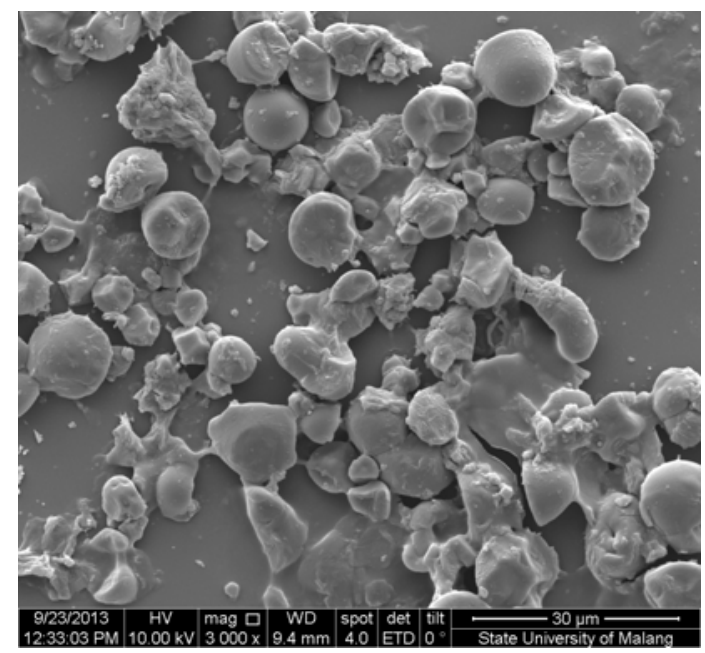

(c)

\section{Aplikasi Tepung Talas Teroksidasi pada Kue Kering}

Uji organoleptik tepung juga dilakukan dengan menggunakan tepung umbi talas Bogor dan tepung umbi talas Bogor teroksidasi (kondisi optimum yaitu konsentrasi suspensi $40 \%$, konsentrasi katalis $0,1 \%$, konsentrasi $\mathrm{H}_{2} \mathrm{O}_{2} 2 \%$ dan temperatur $30^{\circ} \mathrm{C}$ pada waktu oksidasi 30 menit) sebagai bahan baku pembuatan kue kering. Hasil analisanya dapat dilihat pada Tabel 6.

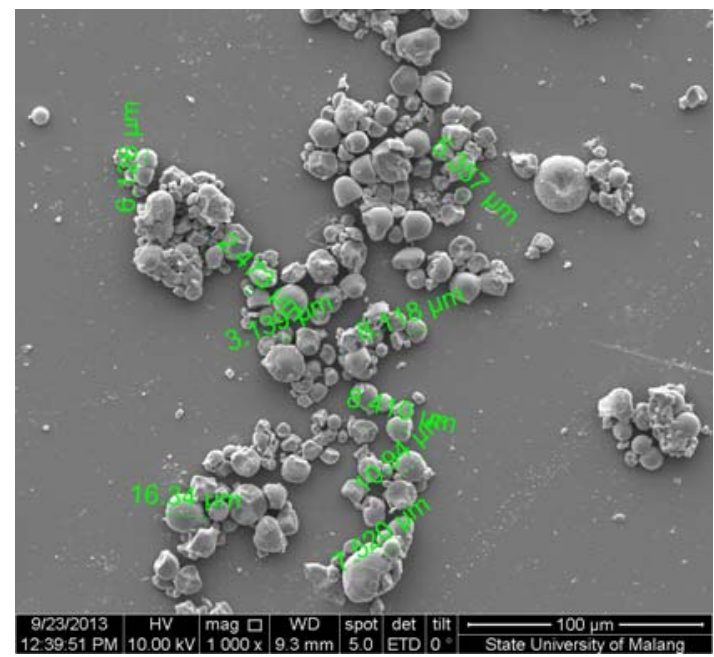

(b)

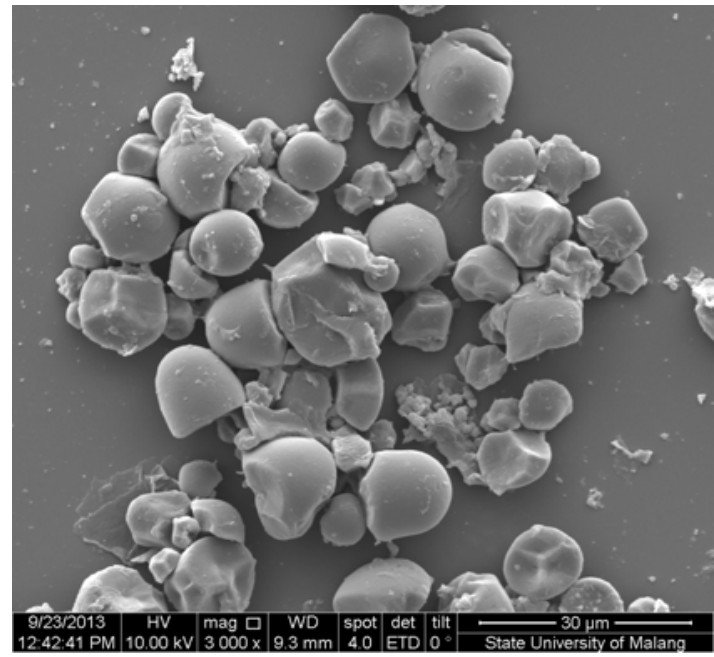

(d)

Gambar 1. Hasil analisis SEM terhadap tepung talas Bogor $(\mathrm{a}, \mathrm{c})$ dan tepung talas teroksidasi (b,d)

Tabel 6. Hasil uji organoleptik kue kering tepung umbi talas Bogor

\begin{tabular}{lcccc}
\hline \multirow{2}{*}{ Jenis Tepung } & \multicolumn{4}{c}{ Uji organoleptik } \\
\cline { 2 - 5 } & Tekstur (Tingkat kerenyahan) & Aroma & Rasa & Warna \\
\hline Tepung terigu (pembanding) & 4,6 & 5 & 5 & 5 \\
Tepung talas Bogor & 2,4 & 1,6 & 2,6 & 3 \\
Tepung talas Bogor teroksidasi & 3,6 & 2,6 & 2,2 & 3 \\
\hline
\end{tabular}

Keterangan: Nilai uji organoleptik: 5 = sangat suka; 4 = suka; 3 = biasa; 2 = tidak suka; 1 = sangat tidak suka 
Kue kering yang berbasiskan tepung umbi talas Bogor memiliki warna coklat keputihan, aromanya agak apek, rasa kurang enak, dan teksturnya lebih keras dibandingkan dengan kue dari tepung terigu. Sementara kue kering yang berbahan baku tepung umbi talas Bogor teroksidasi memiliki warna yang coklat keputihan dengan aroma yang cukup enak, rasa sedikit pahit dan teksturnya lebih rapuh dibandingkan dengan kue kering dari tepung terigu.

\section{KESIMPULAN}

Oksidasi tepung talas Bogor dengan menggunakan oksidator $\mathrm{H}_{2} \mathrm{O}_{2}$ mempengaruhi sifat fungsional dari tepung yaitu daya kembang (swelling power) dan kelarutannya dalam air. Penggunaan konsentrasi suspensi $40 \%$, konsentrasi katalis $0,1 \%$, konsentrasi $\mathrm{H}_{2} \mathrm{O}_{2} 2 \%$ dan temperatur $30^{\circ} \mathrm{C}$ pada waktu oksidasi 30 menit memberikan hasil yang paling optimum ditinjau dari daya kembang (swelling power) dengan nilai $7 \mathrm{~g} / \mathrm{g}$ dan kelarutannya dalam air yaitu $4 \%$ dengan mempertimbangkan aspek teknis dan ekonomis dari proses. Hasil penelitian ini menunjukkan bahwa penggunaan $\mathrm{H}_{2} \mathrm{O}_{2}$ sebagai oksidator cukup efektif dalam meningkatkan nilai daya kembang tepung talas Bogor yang sebelumnya hanya $4,3 \mathrm{~g} / \mathrm{g}$ menjadi $7 \mathrm{~g} / \mathrm{g}$, dimana nilai tersebut telah masuk dalam rasio daya kembang tepung terigu yaitu 6,8-7,9 g/g. Namun oksidator $\mathrm{H}_{2} \mathrm{O}_{2}$ tidak cukup efektif dalam meningkatkan nilai kelarutan tepung dalam air yang sebelumnya hanya $2 \%$ menjadi $4 \%$, dimana nilai tersebut masih di bawah rasio kelarutan tepung terigu yaitu 6,3-7,3\%. Selain itu uji organoleptik pada kue kering berbahan baku tepung umbi talas Bogor teroksidasi menunjukkan kelemahan berupa rasa yang agak pahit dan tekstur yang terlalu rapuh dibandingkan dengan kue kering yang menggunakan bahan baku tepung terigu

\section{UCAPAN TERIMA KASIH}

Penelitian ini didanai dengan DIPA Fakultas Teknik Universitas Diponegoro Tahun 2013. Ucapan terima kasih disampaikan kepada Ratna Oktaviani dan Mirza Septania atas bantuannya dalam pelaksanaan penelitian ini.

\section{DAFTAR PUSTAKA}

Agama-Acevedo, E., Garcia-Suarez, F. J., GutierrezMeraz, F., Sanchez-Rivera, M.M., Martin, E.S. and Bello-Pe' rez, L.A., (2011), Isolation and partial characterization of Mexican taro (Colocasia esculenta L.) starch, Starch, 63, pp.139-146.

Akintayo, C.O. and Akintayo, E.T., (2009), Preparation, Composition and Physico-chemical Characteristics of Native, Oxidized and Acetylated African Yambean (Sphenostylis Sternocarpa) Starches, Advances in Natural and Applied Sciences, 3(2), pp.196-203.
Alam, F. and Hasnain, A., (2009), Studies on Swelling and Solubility of Modified Starch from Taro (Colocasiaesculenta): Effect of $\mathrm{pH}$ and Temperature, Agriculturae Conspectus Scientificus, 74 (1), pp.4550 .

Chan, H.T., Bhat, R., and Karim, A.A., (2009), Physicochemical and Functional Properties of OzoneOxidized Starch. Journal of Agricultural and Food Chemistry, 57, pp. 5965-5970.

Chung, H.J., Shin, D.H., and Lim, S.T., (2008), Invitro starch digestibility and estimated glycemic index of chemically modified corn starches, Food Research International, 41, pp. 579-585.

Kainuma, K., Odat, T., and Cuzuki, S, (1967), Study of starch phosphates monoesters, Journal of Technology Society Starch, 14, pp. 24-28.

Kumoro, A.C., Retnowati, D.S., and Budiyati, C.S., (2010), Microwave Assisted Synthesis and Characterization of Acetate Derivative Cassava Starch, American Journal of Food Technology, 5 (2), pp.100-110.

Kusnandar, F., (2011). Kimia Pangan Komponen Makro, Jakarta: Dian Rakyat.

Leach, H.W., Mc Cowen, L.D., and Schoch, T.J., (1959), Structure of the starch granules. In: swelling and solubility patterns of various starches, Cereal Chemistry, 36, pp. 534-544.

Lee, J.S., Kumar, R.N., Rozman, H.D., and Azemi, B.M.N., (2005), Pasting, swelling, and solubility properties of UV initiated starch-graft-poly (AA). Food Chemistry, 91, pp. 203-211.

Martınez-Bustos, F., Amaya-Llano, S.L., CarbajalArteaga, J.A., Chang, Y.K., and Zazueta-Morale, J.J., (2007), Physicochemical properties of cassava, potato and jicama starches oxidised with organic acids, J. Sci. Food Agric., 87, pp. 1207-1214.

Matsuguma, L.S., Lacerda, L.G., Schnitzler, E., da Silva Carvalho Filho, M.A., Franco, C.M.L., and Demiate, I.M., (2009), Characterization of Native and Oxidized Starches of Two Varieties of Peruvian Carrot (Arracacia xanthorrhiza, B.) from Two Production Areas of Paraná State, Brazil. Brazilian Archives of Biology and Technology, 52(3), pp. 701713.

Niba, L.L., (2003), Processing effects on susceptibility of starch to digestion in some dietary starch sources. International Journal of Food Sciences and Nutrition, 54, pp. 97-109.

Onwueme, I.C., (1978), Strategies for increasing cocoyam (Colocasia Xanthosoma sp), In Nigeria Food 
Reaktor, Vol. 15 No. 1, April 2014, Hal. 1-9

Basket paper Presented at the First National Workshop on Cocoyam NRCRI-Umudike, Nigeria.

Parovuori, P., Hamunen, A., Forssell, P., Autio, K., and Poutanen, K. (1995), Oxidation of potato starch by hydrogen peroxide. Starch/Sta"rke, 47(1), pp.1923.

Tethool, E.F., (2012), Pengaruh Konsentrasi Hidrogen Peroksida dan Irradiasi Ultraviolet terhadap Sifat Fisikokimia dan Baking Expansion Pati Sagu, Prosiding InSINas, 2012.

Tolvanen, P., Sorokin, A.B., Mäki-Arvela, P., Murzin, D.Y., and Tapio Salmi, T., (2013), Oxidation of Starch by $\mathrm{H}_{2} \mathrm{O}_{2}$ in the Presence of Iron Tetrasulfophthalocyanine Catalyst: The Effect of
Catalyst Concentration, pH, Solid-Liquid Ratio, and Origin of Starch, Industrial Engineering Chemistry Research, 52, pp. 9351-9358.

Wang, Y.J. and Wang, L., (2003), Physicochemical properties of common and waxy corn starches oxidized by different levels of sodium hypochlorite. Carbohydrate Polymers, 52, pp. 207-217.

Wing, R.E. and Willett, J.L., (1997), Water soluble oxidized starches by peroxide reactive extrusion. Ind Crops Prod, 7, pp. 45-52.

Zhang, Y.R., Wang, X.L., Zhao, G.M. and Wang, Y.Z., (2012), Preparation and properties of oxidized starch with high degree of oxidation, Carbohydrate Polymers, 87, pp. 2554- 2562. 